\title{
Preservation of Raw Camel Milk by Lactoperoxidase System Using Hydrogen Peroxide Producing Lactic Acid Bacteria
}

\author{
Dakalo Dashe1, Egon Bech Hansen², Mohammed Yusuf Kurtu1, Tesfemariam Berhe1, \\ Mitiku Eshetu1, Yonas Hailu' ${ }^{1}$, Amsalu Waktola1, Adane Shegaw ${ }^{1}$ \\ ${ }^{1}$ School of Animal and Range Sciences, Haramaya University, Dire Dawa, Ethiopia \\ ${ }^{2}$ Division for Diet, Disease Prevention and Toxicology, National Food Institute, Technical University of Denmark, Kgs. Lyngby, \\ Denmark \\ Email: mitikuguya@yahoo.com,dfdaki@gmail.com
}

How to cite this paper: Dashe, D., Hansen, E.B., Kurtu, M.Y., Berhe, T., Eshetu, M., Hailu, Y., Waktola, A. and Shegaw, A. (2020) Preservation of Raw Camel Milk by Lactoperoxidase System Using Hydrogen Peroxide Producing Lactic Acid Bacteria. Open Journal of Animal Sciences, 10, 387-401. https://doi.org/10.4236/ojas.2020.103024

Received: April 10, 2020

Accepted: June 8, 2020

Published: June 11, 2020

Copyright $\odot 2020$ by author(s) and Scientific Research Publishing Inc. This work is licensed under the Creative Commons Attribution International License (CC BY 4.0).

http://creativecommons.org/licenses/by/4.0/

(c) (i) Open Access

\begin{abstract}
This study was conducted to investigate the effect of lactic acid bacteria (LAB) activated lactoperoxidase system (LPs) on keeping quality of raw camel milk at room temperature. Camel milk samples were collected from Errer valley, Babile district of eastern Ethiopia. The level of hydrogen peroxide $\left(\mathrm{H}_{2} \mathrm{O}_{2}\right)$ for activation of LPs was optimized using different levels of exogenous $\mathrm{H}_{2} \mathrm{O}_{2}$. Strains of LAB (Lactococcus lactis 22333, Weissella confusa 22308, W. confusa 22282, W. confusa 22296, S. Infatarius 22279 and $S$. Iutetiensis 22319) with $\mathrm{H}_{2} \mathrm{O}_{2}$ producing properties were evaluated, and $W$. confusa 22282 was selected as the best strain to produce $\mathrm{H}_{2} \mathrm{O}_{2}$. Storage stability of the milk samples was evaluated through the acidification curves, titratable acidity (TA), total bacterial count (TBC) and coliform counts (CC) at storage times of 0,6,12, 18, 24 and 48 hours. The LP activity and the inhibitory effect of activated LPs were evaluated by growing E. coli in pasteurized and boiled camel milk samples as contaminating agent. Results indicated that the W. confusa 22282 activated LPs generally showed significantly $(\mathrm{P}<0.05)$ slower rates of acidification, lactic acid production and lower TBC and CC during the storage time compared to the non-activated sample. The $\mathrm{H}_{2} \mathrm{O}_{2}$ producing $\mathrm{LAB}$ and exogenous $\mathrm{H}_{2} \mathrm{O}_{2}$ activated LPs in pasteurized camel milk significantly reduced the growth of $E$. coli population compared to non-activated pasteurized milk. Overall, the result of acid production and microbial analysis indicated that the activation of LPs by $\mathrm{H}_{2} \mathrm{O}_{2}$ producing LAB (i.e. W. confusa 22282) maintained the storage stability of raw camel milk. Therefore, it can be concluded that the activation of LPs by biological method using $\mathrm{H}_{2} \mathrm{O}_{2}$ producing LAB can substitute the chemical activation method of LPs in camel milk.
\end{abstract}




\section{Keywords}

Camel Milk, Lactoperoxidase System, Lactic Acid Bacteria, Preservation

\section{Introduction}

Camels are important source of livelihood for millions of people living in the arid and semi-arid areas of many parts of the world, providing food, cash income and transport and have significant cultural values to the pastoral communities [1]. Camels are mainly kept for milk production and can produce milk for a longer period of time even during dry season [2] [3]. Camel milk has been traditionally consumed raw or in the form of fermented milk at household level for years with only limited amount being sold [4]. The changes in life styles such as fast-growing population, intensified growth of small towns and commercialization of pastoral products in the lowlands increased the demand for camel milk [5]. This condition opened market opportunities for the pastoral communities and peri-urban milk producers [6] [7].

However, camel milk is usually transported without cooling facilities for long distances to reach to the consumers or processing point which increased concerns over the microbiological quality of the milk [8]. Microbial growth is a major concern of public health as some can potentially cause milk-borne illness [9]. Milk with high levels of microbial contamination is not safe for direct consumption or it cannot be processed into different dairy products [10]. Therefore, prevention of quality loss through inhibition of bacterial growth during collection, transportation and storage of raw milk is of paramount importance. Several preservation techniques including cooling, heat treatment, acidification and addition of chemicals have been used at different levels from production to processing to prevent growth of spoilage and pathogenic microorganisms in foods [11]. Cooling of fresh milk during collection and transportation is widely used in most parts of the world especially in the developed countries [12].

In the areas where cooling facilities are unavailable to preserve raw milk due to economic and technical reasons, the International Dairy Federation [13] and Joint Food and Agricultural and World Health Organizations [14] had developed a method to increase the storage stability of the milk. The method is based on activating natural antibacterial system in raw milk which consists of lactoperoxidase (LP), thiocyanate $\left(\mathrm{SCN}^{-}\right)$and hydrogen peroxide $\left(\mathrm{H}_{2} \mathrm{O}_{2}\right)$. The LPs is commonly activated by exogenously increasing the concentrations of the thiocyanate and $\mathrm{H}_{2} \mathrm{O}_{2}$ [15]. However, consumer awareness and concern regarding chemical additives and the demand for safe foods have led to find alternatives in food preservation [16]. In this regard, an emerging preservation technique is demanded via activating the LPs by lactic acid bacteria (LAB). Lactic acid bacteria are capable of producing several metabolites including organic acids, $\mathrm{H}_{2} \mathrm{O}_{2}$ and bacteriocins, which have antagonistic effect to a wide range of microorgan- 
isms [17].

Hydrogen peroxide producing $L A B$ was reported to inhibit growth of spoilage and pathogenic microorganisms [18]. This effect, however, might be due to the hydrogen peroxide produced or by the activated LPs from the production of $\mathrm{H}_{2} \mathrm{O}_{2}$ in the milk. Previous work [19] indicated some strains of LAB (Lactococcus lactis 22333, W. confusa 22308, W. Confusa 22282, W. confusa 22296, S. Infatarius 22279 and $S$. lutetiensis 22319) isolated from camel milk can produce $\mathrm{H}_{2} \mathrm{O}_{2}$. However, the effect of these strains on the LPs activation properties is not evaluated. Besides, there is no information on the use of the $\mathrm{H}_{2} \mathrm{O}_{2}$ producing $\mathrm{LAB}$ to activate the LPs and extend the keeping quality of raw camel milk. Therefore, this study was conducted to evaluate the effect of LAB activated LPs on the storage stability of raw camel milk at ambient temperature.

\section{Materials and Methods}

\subsection{Collection of Milk Samples}

The milk samples were collected from Errer valley, Babile District of eastern Ethiopia, about $30 \mathrm{~km}$ from Harar city. Errer valley is located at $9^{\circ} 14^{\prime} \mathrm{N}$ latitude and $42^{\circ} 14^{\prime} \mathrm{E}$ longitude at an altitude of 1300 - 1600 m.a.s.l. The milk was collected in clean and sterilized plastic containers from four households of five lactating camels at different parities and stage of lactations. The samples were pooled and packed under icebox and transported to Haramaya University Dairy Technology Laboratory. Milk samples were collected three times for each experiment and analysis was done in duplicates. The milk samples to be preserved with LPs were activated within $2 \mathrm{hrs}$ of collection, as the indigenous antimicrobial activity in the freshly drawn milk is usually used up within 2 - 3 hrs due to suboptimal levels of the thiocyanate ion and hydrogen peroxide in the milk according to Codex Alimentarius Commission.

\subsection{Determination of Thiocyanate Concentration}

The thiocyanate concentration naturally present in camel milk samples was determined by spectrophotometer (3605, Jenway) at an absorbance of $460 \mathrm{~nm}$, after deproteinisation of the milk with trichloroacetic acid (TCA) (Sigma-Aldrich T6399) and addition of ferric nitrate to form a ferric complex (orange to orange-red). Four millilitres $(4.0 \mathrm{ml}$ ) of milk was mixed with $2.0 \mathrm{ml}$ of $20 \%$ TCA solution. The mixture was mixed well and allowed to stand for 30 minutes. The solution was filtered through a filter paper (Whatman No. 40). One and half (1.5 $\mathrm{ml}$ ) of the clear filtrate was then mixed with $1.5 \mathrm{ml}$ of the ferric nitrate reagent and the absorbance was measured at $460 \mathrm{~nm}$ using spectrophotometer. The thiocyanate concentration was calculated from a standard curve prepared using known concentrations of sodium thiocyanate (Alfa Aesar 33388) [13].

\subsubsection{Growth of Lactic Acid Bacteria and Quantification of Hydrogen Peroxide \\ Strains of $\mathrm{LAB}$ producing $\mathrm{H}_{2} \mathrm{O}_{2}$ (Lactococcus lactis 22333, W. confusa 22308, W.}


confusa 22282, W. confusa 22296, S. infatarius 22279, S. lutetiensis 22319) were obtained from Technical University of Denmark (DTU), Copenhagen. The strains were originally isolated from camel milk from Babile area of eastern Ethiopia and were characterized by their $\mathrm{H}_{2} \mathrm{O}_{2}$ production properties [19]. The strains were maintained on de Mann Rogosa Sharpe (MRS) agar and allowed to grow on Prussian blue (PB) agar, in MRS broth (Sigma-Aldrich 6966) and in pasteurized camel milk for detection and quantification of the $\mathrm{H}_{2} \mathrm{O}_{2}$ produced.

The test organisms previously grown on MRS agar were also inoculated into MRS broth at room temperature for 72 hours and centrifuged (Sigma ${ }^{\circledR} 3-30 \mathrm{KS}$ ) at $10,000 \mathrm{rpm}$ for 15 minutes at $4^{\circ} \mathrm{C}$. Protenase $\mathrm{K}$ enzyme (Sigma-Aldrich P6556) $(5 \mathrm{mg} / \mathrm{ml})$ was added to cell free extract solution to exclude the antimicrobial effect of bacteriocins, and $\mathrm{pH}$ was adjusted to 7.0 by means of $0.1 \mathrm{~N}$ $\mathrm{NaOH}$ to reduce the effect organic acids. The supernatant was filtered through $0.2 \mathrm{~mm}$ pore size cellulose acetate filter. Twenty-five millilitres $(25 \mathrm{ml})$ of supernatant of broth cultures of the test organisms was measured into a $100 \mathrm{ml}$ flask to which $25 \mathrm{ml}$ of dilute $\mathrm{H}_{2} \mathrm{SO}_{4}$ was added. This solution was then titrated with $0.1 \mathrm{~N}$ Potassium permanganate $\left(\mathrm{KMnO}_{4}\right)$. Each millilitre of $0.1 \mathrm{~N} \mathrm{KMnO}_{4}$ used was assumed to be equivalent to $1.701 \mathrm{mg}$ of $\mathrm{H}_{2} \mathrm{O}_{2}$. The decolourization of the sample was regarded as the end point. The volume of $\mathrm{H}_{2} \mathrm{O}_{2}$ produced was calculated according to AOAC [20].

$$
\% \mathrm{H}_{2} \mathrm{O}_{2}=\frac{\mathrm{ml} \mathrm{KMnO}_{4} \times \mathrm{N} \mathrm{KMnO}_{4} \times \mathrm{M} . \mathrm{E}}{\mathrm{ml} \mathrm{H}_{2} \mathrm{SO}_{4} \times \text { Volume of sample }} \times 100
$$

where: $\mathrm{KMnO}_{4}=$ volume of $\mathrm{KMnO}_{4}$ used $(\mathrm{ml}), \mathrm{N} \mathrm{KMnO}_{4}=$ concentration of $\mathrm{KMnO}_{4}$ used (Normality), M.E = equivalence factor, $\mathrm{ml} \mathrm{H}_{2} \mathrm{SO}_{4}=$ volume of $\mathrm{H}_{2} \mathrm{SO}_{4}$ used.

\subsubsection{Preparation of Inoculum and Determination of Acidification Curves}

Fresh camel milk was divided into glass containers of $30 \mathrm{ml}$ and boiled for 30 minutes at $90^{\circ} \mathrm{C}$. The samples were cooled to room temperature and inoculated with single colonies of LAB from agar plates. The bacterial cultures were incubated at $30^{\circ} \mathrm{C}$ for $18 \mathrm{hrs}$ and the mother culture was sealed and frozen at $-20^{\circ} \mathrm{C}$ until used [19].

Fresh camel milk samples of $200 \mathrm{ml}$ were pasteurized in autoclavable bottles at $64^{\circ} \mathrm{C}$ for $30 \mathrm{~min}$. The samples were cooled to room temperature and inoculated with $1 \%$ of the mother culture. The acidification curves were followed using iCinac (Alliance Instruments, Frepillon, France). Calibrated and disinfected iCinac $(\mathrm{pH})$ probes were inserted into the milk samples to ferment in a water bath at room temperature for 48 hours while the instrument continuously measures $\mathrm{pH}$ for every minute [19].

\subsection{Effect of Lactoperoxidase System Activation on the Storage Stability of Camel Milk}

An optimization experiment for the level of exogenous $\mathrm{H}_{2} \mathrm{O}_{2}$ to activate LPs was 
conducted using TBC and titratable acidity, considering $30 \mathrm{ppm}$ to be used as a positive control in this experiment. Weissella confusa 22282 was selected for activation of the LPs due to its better $\mathrm{H}_{2} \mathrm{O}_{2}$ production in MRS broth and reduction in acidification rate in pasteurized camel milk. Mother culture of the strain was prepared by inoculating the strain into MRS broth for 72 hours at $30^{\circ} \mathrm{C}$ and activating culture was prepared by growing the culture from the MRS broth in skim milk at a rate of $100 \mathrm{mg} / \mathrm{L}$ at $22^{\circ} \mathrm{C}$ for 16 hours [21]. The culture was inoculated into raw camel milk at rate of $1 \%$ and shelf life of the milk samples was evaluated through the $\mathrm{pH}$ (acidification curves), TA, TBC and CC at storage times of $0,6,12,18,24$ and 48 hours. Raw milk with no addition and $30 \mathrm{ppm}$ $\mathrm{H}_{2} \mathrm{O}_{2}$ were used as negative and positive controls respectively (Table 1).

The TBC was done by pour plate method using standard plate count (SPC) agar (Sigma-Aldrich 70152). Plates with colonies ranging from 30 - 300 were counted and expressed as colony forming units per millilitre ( $\mathrm{cfu} / \mathrm{ml})$ according to IDF [22]. The titratable acidity was determined by titrating the milk sample with $0.1 \mathrm{~N} \mathrm{NaOH}$ (Himedia MB09) using a phenolphthalein indicator to an end-point of faint pink colour [23]. Coliform count was done by pour plate method using violet red bile agar (VRBA) (Sigma-Aldrich 70188). Plates with 15 to $150 \mathrm{cfu} / \mathrm{mL}$ were used for determining total coliform counts [22].

\subsection{Growth of Escherichia coli in Lactoperoxidase System Activated Camel Milk}

The activity of lactoperoxidase in the milk and the effect of activated LPs on Escherichia coli were evaluated by growing the bacteria $(E$. coli ATCC 25922) in pasteurized and boiled camel milk samples. Weissela confusa $22282(1 \%, \mathrm{~V} / \mathrm{V})$ and exogenous $\mathrm{H}_{2} \mathrm{O}_{2}(30 \mathrm{ppm})$ were used as a source of $\mathrm{H}_{2} \mathrm{O}_{2}$ to activate the LPs in both pasteurized and boiled milk samples (Table 2). Changes in E. coli population

Table 1. Effect of LPs activation on the storage stability of camel milk.

\begin{tabular}{ccc}
\hline Treatments & Descriptions & Storage time (h) \\
\hline $\mathrm{T}_{1}$ & Raw milk & $0,6,12,18,24$ and 48 \\
$\mathrm{~T}_{2}$ & Raw milk + W. confusa 22282 culture $(1 \%, \mathrm{~V} / \mathrm{V})$ & $0,6,12,18,24$ and 48 \\
$\mathrm{~T}_{3}$ & Raw milk $+30 \mathrm{ppm} \mathrm{H}_{2} \mathrm{O}_{2}$ & $0,6,12,18,24$ and 48 \\
\hline
\end{tabular}

Table 2. Lactoperoxidase activity and effect of activation of LPs on E. coli in camel milk.

\begin{tabular}{|c|c|c|}
\hline Treatments & Description & Storage time $(\mathrm{h})$ \\
\hline $\mathrm{T}_{1}$ & Pasteurized milk & $0,6,12,18,24$ and 48 \\
\hline $\mathrm{T}_{2}$ & Pasteurized milk $+W$. confusa 22282 culture $(1 \%, \mathrm{~V} / \mathrm{V})$ & $0,6,12,18,24$ and 48 \\
\hline $\mathrm{T}_{3}$ & Pasteurized milk $+30 \mathrm{ppm} \mathrm{H}_{2} \mathrm{O}_{2}$ & $0,6,12,18,24$ and 48 \\
\hline $\mathrm{T}_{4}$ & Boiled milk & $0,6,12,18,24$ and 48 \\
\hline $\mathrm{T}_{5}$ & Boiled milk $+W \cdot$ confusa 22282 culture $(1 \%, \mathrm{~V} / \mathrm{V})$ & $0,6,12,18,24$ and 48 \\
\hline $\mathrm{T}_{6}$ & Boiled milk +30 ppm $\mathrm{H}_{2} \mathrm{O}_{2}$ & $0,6,12,18,24$ and 48 \\
\hline
\end{tabular}


were evaluated at storage times of $0,6,12,18,24$ and 48 hours at room temperature.

Temperatures of $63^{\circ} \mathrm{C} / 30$ minutes and $80^{\circ} \mathrm{C} / 15$ seconds were used for pasteurizing and boiling the milk samples, respectively. The E. coli (ATCC 25922) culture were obtained from Haramaya University Pathology Laboratory and maintained on MacConkey agar plates at $32^{\circ} \mathrm{C}$ for 24 hours. Working cultures was prepared by transferring a single colony of $E$. coli from MacConkey agar into sterile Tryptone Soy Broth (TSB) (Sisco 24392 (TM 018)) to incubate for 24 hours at $37^{\circ} \mathrm{C}$. Contaminating inoculum of the $E$. coli was prepared by transferring $0.5 \mathrm{ml}$ of the working culture into $100 \mathrm{ml}$ sterile TSB for 24 hours at $37^{\circ} \mathrm{C}$ [21]. The contaminating culture was then aseptically added to all the test samples at a rate $0.25 \%$ [24]. The respective test samples were then inoculated with $1 \%(\mathrm{~V} / \mathrm{V}) W$. confusa 22282 cultures and $30 \mathrm{ppm} \mathrm{H}_{2} \mathrm{O}_{2}$ in both pasteurized and boiled milk samples and left at room temperature for the period of 48 hours (Table 2). Cultures from the milk samples were plated on MacConkey agar and incubated at $32^{\circ} \mathrm{C}$ for 24 hours [25].

\subsection{Statistical Analysis}

General linear model (GLM) procedure of SAS version 9.0 was employed to determine the significance between treatment means at a particular storage period. Mean separations were done using least significant difference (LSD) for variables whose F values were significantly different. Significant differences were calculated at 5\% significance level. Descriptive statistics was used to calculate means and standard deviations of chemical compositions and amount of $\mathrm{H}_{2} \mathrm{O}_{2}$ produced.

\section{Results and Discussion}

\subsection{Thiocyanate Concentration of Camel Milk}

The natural thiocyanate content in the present study was $22.34 \pm 5.11 \mathrm{mg} / \mathrm{L}$ that falls within the ranges reported earlier (9.74 to $32.9 \mathrm{mg} / \mathrm{L}$ ) [26] and (9.7 to 36.4 $\mathrm{mg} / \mathrm{L})$ [27] and higher than the level found (6.04 mg/L) [28] from Erer valley of eastern Ethiopia. Natural thiocyanate content of 7.38 was found from cow milk in Kombolchadistrict, eastern Hararghe of Ethiopia [29].

The higher thiocyanate content in the present study compared to the finding from the same area [28] might be due to differences in analytical measurements, feeding system and environmental conditions. Several factors could affect the thiocyanate concentration of milk such as age of the animal, health of the animal, species of animal, breed, lactation stage and nutritional condition among which the kind of feed supplied plays a major role [30]. Thiocyanate content might also vary among season of the year where the level in summer was higher than the thiocyanate concentration in winter [31]. Camels in the Erer valley of Babile area spend during the day outdoors browsing different types of plants including herbaceous plants, shrubs, shoots, cacti and different types of acacia 
trees. Acacia trees and shrubs are expected to have high contents of cyanogenic glycosides which are a precursor of thiocyanate in plants [32].

The SCN value in the current study is higher than the concentration (15 ppm) required for the activation of the LPs according to Codex Alimentarius Commission [33]. The present finding is therefore showed that LPs in camel milk can be activated by natural SCN content in the milk with the addition of only desired amount of $\mathrm{H}_{2} \mathrm{O}_{2}$ [27].

\subsection{Production of Hydrogen Peroxide by Lactic Acid Bacteria}

The result of the acidification for the $\mathrm{H}_{2} \mathrm{O}_{2}$ producing strains of LAB indicated that $W$. confusa 22282 and $S$. infantarius 22279 are slow acidifying strains while L. lactis 22333 showed fast acidification in pasteurized camel milk at room temperature. L. lactis 22333 attained a $\mathrm{pH}$ of 4.3 at around 24 hours of storage while the $\mathrm{pH}$ in the $W$. confusa 22282 and $S$. infantarius 22279 treated samples shown no change $(\mathrm{pH}>6.4)$ until the end of the storage period. The control treatment (pasteurized milk without LAB) started to drop at about 32 hours of storage and become below $\mathrm{pH} 6.4$ at the end of the storage (Figure 1). This indicated that camel milk treated with $W$. confusa 22282 and S. infantarius 22279 had better stability compared to the control samples.

Similarly, the result of the $\mathrm{H}_{2} \mathrm{O}_{2}$ quantification by titration showed that $W$. confusa 22282 produced significantly $(\mathrm{P}<0.05)$ the highest amount of $\mathrm{H}_{2} \mathrm{O}_{2}$ (302.10 \pm 20.55$)$ in the MRS broth. Lactococcus lactis 22333 produced significantly $(\mathrm{P}<0.05)$ the least amount of $\mathrm{H}_{2} \mathrm{O}_{2}(84.37 \pm 24.53)$ in MRS broth (Table 3). All the strains except L. lactis 22333 were observed to grow yielding a deep blue colour around the colonies on $\mathrm{PB}$ agar due to reaction of $\mathrm{H}_{2} \mathrm{O}_{2}$ to hexacyanoferrate (III) and iron (III) [34]. The overall results of $\mathrm{H}_{2} \mathrm{O}_{2}$ indicated that $W$. confusa 22282 was the promising strain to use for activation of the antimicrobial system in raw camel milk.

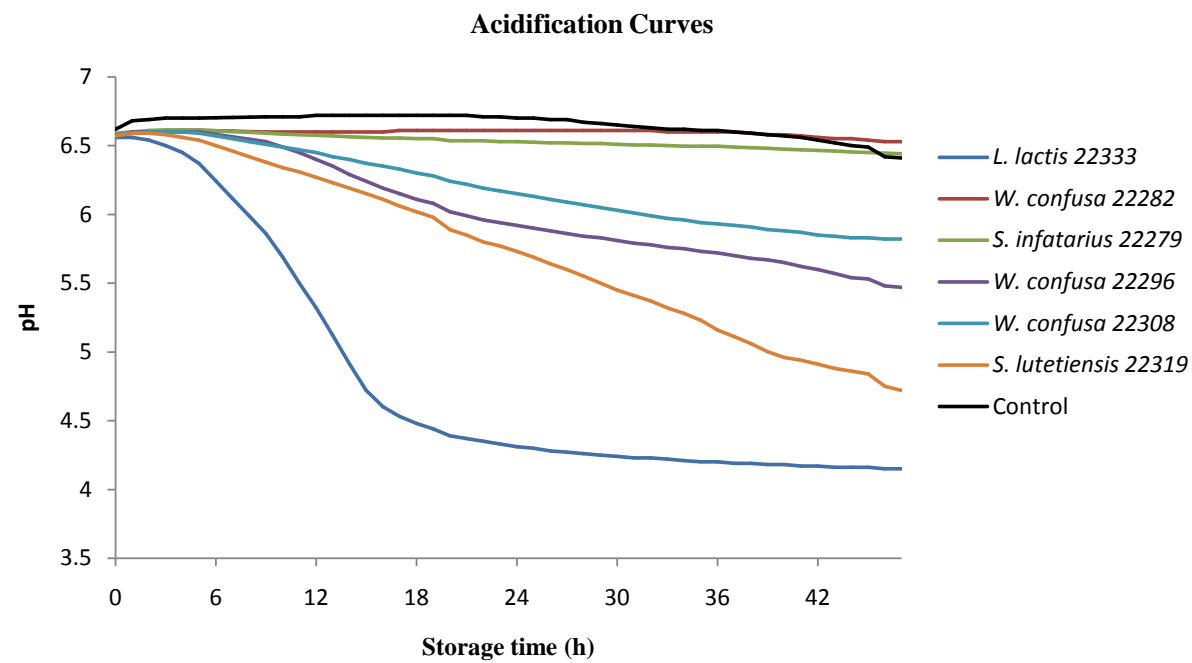

Figure 1. Acidification curves for $\mathrm{H}_{2} \mathrm{O}_{2}$ producing LAB strains in pasteurized camel milk $\left(21^{\circ} \mathrm{C}-23^{\circ} \mathrm{C}\right)$. 
Table 3. Production of $\mathrm{H}_{2} \mathrm{O}_{2}$ by LAB in MRS broth (Mean \pm SD).

\begin{tabular}{cc}
\hline Strains of $\mathrm{LAB}$ & Concentration of $\mathrm{H}_{2} \mathrm{O}_{2}(\mathrm{mg} / \mathrm{L})$ \\
\hline L. lactis 22333 & $84.37 \pm 24.53^{\mathrm{e}}$ \\
W. confusa 22382 & $302.10 \pm 20.55^{\mathrm{a}}$ \\
W. confusa 22296 & $260.82 \pm 25.29^{\mathrm{b}}$ \\
W. confusa 22308 & $220.45 \pm 19.63^{\mathrm{c}}$ \\
S. Iutetiensis 22319 & $174.64 \pm 13.08^{\mathrm{d}}$ \\
S. infatarius 22279 & $255.38 \pm 12.86^{\mathrm{cb}}$ \\
\hline
\end{tabular}

The production of $\mathrm{H}_{2} \mathrm{O}_{2}$ by LAB in MRS broth in the current study is higher than the results reported by earlier researchers [35] [36]. Hydrogen per oxide yield of $0.4279 \mathrm{mg} / \mathrm{L}$ in MRS broth from L. Lactis [35], and Leuconostoc mesenteroides produced higher quantity of $\mathrm{H}_{2} \mathrm{O}_{2}(24 \mathrm{mg} / \mathrm{L})$ in normal MRS broth at $30^{\circ} \mathrm{C}$ for 48 hours of incubation period [36]. However, higher concentration of $350 \mathrm{mg} / \mathrm{L}$ of $\mathrm{H}_{2} \mathrm{O}_{2}$ from L. lactis subsp. lactis suspended in $0.5 \%(\mathrm{w} / \mathrm{v})$ glucose plus $0.5 \%(\mathrm{w} / \mathrm{v})$ lactate $(\mathrm{pH} 7.0)$ and incubated for 5 hours at $37^{\circ} \mathrm{C}$ under aeration was also reported [37].

\subsection{Effect of Activation of LPs by Weissella confusa 22282 on Storage Stability of Camel Milk}

The activation of LPs by $W$. confusa 22282 and exogenous $\mathrm{H}_{2} \mathrm{O}_{2}$ in raw camel milk significantly $(\mathrm{P}<0.05)$ reduced the rate of acidification, TBC and $\mathrm{CC}$. The values of $\mathrm{pH}$ (Figure 2) and lactic acid percentage (Table 4) in the activated samples for 18 hours of storage were within the acceptable level of $\mathrm{pH}$ and lactic acid of fresh camel milk, respectively. This could be due to retarded microbial growth as a result of antimicrobial properties of the LPs in activated samples. Decrease in lactic acid production was observed in LPs activated camel milk samples [27] [28] and other finding reported that there is less production of lactic acid in the LPs activated milk samples compared to the control sample because of the inhibitory nature of LPs [38].

The TBC and CC were significantly $(\mathrm{P}<0.05)$ reduced in the treated samples compared to the non-activated control sample at 12, 18, 24 and 48 hours of storage. The TBC count in the $\mathrm{LAB}$ activated and $\mathrm{H}_{2} \mathrm{O}_{2}$ activated LPs samples were decreased by 1.61 and $1.66 \mathrm{log}$ units, respectively compared to the non-activated sample at 18 hours of storage. On the other hand, TBC in the exogenous $\mathrm{H}_{2} \mathrm{O}_{2}$ activated LPs decreased below the initial value for up to 12 hours and then slightly increased toward the end of storage period. The LAB activated LPs sample shown nearly constant rate in bacterial reduction throughout the storage period compared to the $\mathrm{H}_{2} \mathrm{O}_{2}$ activated milk indicating that LAB can constantly produce $\mathrm{H}_{2} \mathrm{O}_{2}$ and other inhibitory components which have antagonistic effect on the microbial population. This finding can be supported by other findings [39] that the activation of the LPs may induce a longer-lasting bacteriostatic 
Table 4. Effect of activation method of LPs on lactic acid development (\%), TBC and CC $\left(\log _{10} \mathrm{cfu} \mathrm{mL}^{-1}\right)($ Mean $\pm \mathrm{SD})$ in raw camel milk.

\begin{tabular}{ccccccc}
\hline \multirow{2}{*}{ Treatments } & \multicolumn{5}{c}{ Storage time (h) } \\
\cline { 2 - 6 } & Initial & 6 & 12 & 18 & 24 & 48 \\
\hline Lactic acid & & & & & \\
$\mathrm{T}_{1}$ & $0.12 \pm 0.01^{\mathrm{a}}$ & $0.14 \pm 0.01^{\mathrm{a}}$ & $0.17 \pm 0.01^{\mathrm{a}}$ & $0.22 \pm 0.01^{\mathrm{a}}$ & $0.34 \pm 0.02^{\mathrm{a}}$ & $0.63 \pm 0.03^{\mathrm{a}}$ \\
$\mathrm{T}_{2}$ & $0.12 \pm 0.01^{\mathrm{a}}$ & $0.12 \pm 0.01^{\mathrm{b}}$ & $0.14 \pm 0.01^{\mathrm{b}}$ & $0.16 \pm 0.01^{\mathrm{b}}$ & $0.20 \pm 0.01^{\mathrm{b}}$ & $0.41 \pm 0.04^{\mathrm{b}}$ \\
$\mathrm{T}_{3}$ & $0.12 \pm 0.01^{\mathrm{a}}$ & $0.12 \pm 0.01^{\mathrm{b}}$ & $0.13 \pm 0.01^{\mathrm{b}}$ & $0.15 \pm 0.00^{\mathrm{b}}$ & $0.21 \pm 0.01^{\mathrm{b}}$ & $0.48 \pm 0.02^{\mathrm{c}}$ \\
$\mathrm{TBC}$ & & & & & & \\
$\mathrm{T}_{1}$ & $5.12 \pm 0.48^{\mathrm{a}}$ & $5.58 \pm 0.48^{\mathrm{a}}$ & $6.48 \pm 0.59^{\mathrm{a}}$ & $7.29 \pm 0.80^{\mathrm{a}}$ & $8.42 \pm 0.72^{\mathrm{a}}$ & $9.67 \pm 0.04^{\mathrm{a}}$ \\
$\mathrm{T}_{2}$ & $5.12 \pm 0.48^{\mathrm{a}}$ & $5.17 \pm 0.57^{\mathrm{a}}$ & $5.23 \pm 0.62^{\mathrm{b}}$ & $5.68 \pm 0.61^{\mathrm{b}}$ & $6.23 \pm 0.58^{\mathrm{b}}$ & $7.42 \pm 0.22^{\mathrm{b}}$ \\
$\mathrm{T}_{3}$ & $5.12 \pm 0.48^{\mathrm{a}}$ & $5.06 \pm 0.50^{\mathrm{a}}$ & $5.10 \pm 0.50^{\mathrm{b}}$ & $5.63 \pm 0.57^{\mathrm{b}}$ & $6.53 \pm 0.56^{\mathrm{b}}$ & $7.87 \pm 0.55^{\mathrm{b}}$ \\
$\mathrm{CC}$ & & & & & & \\
$\mathrm{T}_{1}$ & $4.39 \pm 0.17^{\mathrm{a}}$ & $4.87 \pm 0.49^{\mathrm{a}}$ & $5.52 \pm 0.15^{\mathrm{a}}$ & $6.18 \pm 0.53^{\mathrm{a}}$ & $7.08 \pm 0.51^{\mathrm{a}}$ & $8.22 \pm 0.59^{\mathrm{a}}$ \\
$\mathrm{T}_{2}$ & $4.39 \pm 0.17^{\mathrm{a}}$ & $4.40 \pm 0.15^{\mathrm{a}}$ & $4.66 \pm 0.49^{\mathrm{b}}$ & $5.09 \pm 0.54^{\mathrm{b}}$ & $5.78 \pm 0.58^{\mathrm{b}}$ & $6.78 \pm 0.34^{\mathrm{b}}$ \\
$\mathrm{T}_{3}$ & $4.39 \pm 0.17^{\mathrm{a}}$ & $4.37 \pm 0.20^{\mathrm{a}}$ & $4.53 \pm 0.13^{\mathrm{b}}$ & $5.21 \pm 0.19^{\mathrm{b}}$ & $6.06 \pm 0.35^{\mathrm{b}}$ & $7.26 \pm 0.56^{\mathrm{ba}}$ \\
\hline
\end{tabular}

$\mathrm{T}_{1}=$ Raw camel milk (without preservative), $\mathrm{T}_{2}=$ Raw camel milk $+W$. confusa 22282 culture, $\mathrm{T}_{3}=$ Raw camel milk $+\mathrm{H}_{2} \mathrm{O}_{2}$. Means bearing different superscript letters within the same column are significantly different $(\mathrm{P}<0.05)$.

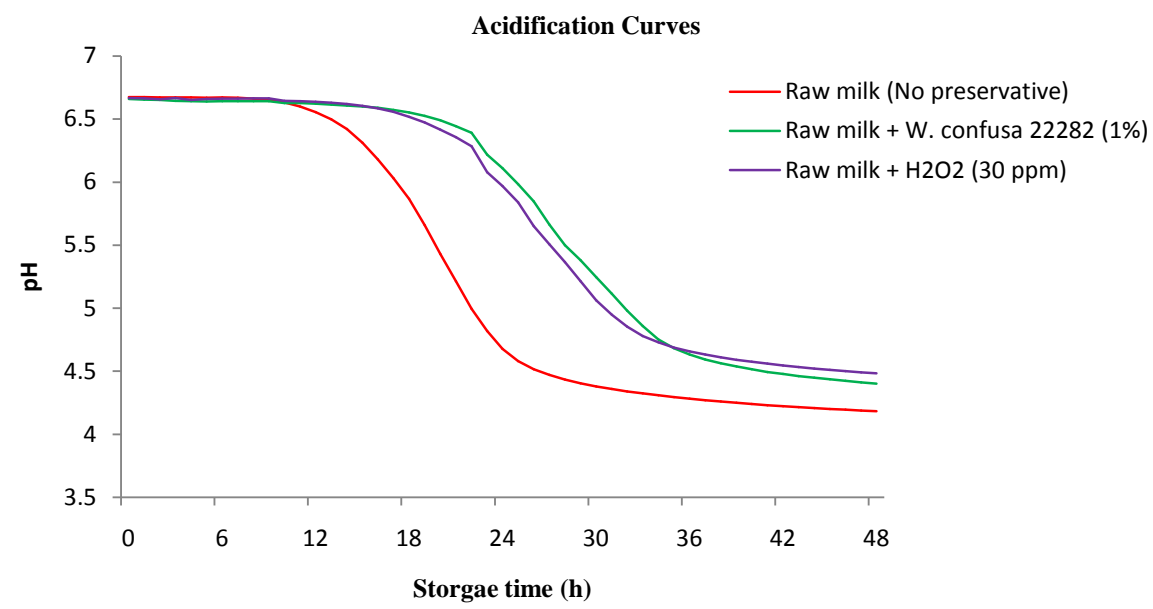

Figure 2. Acidification curves for W. confusa 22282 and $\mathrm{H}_{2} \mathrm{O}_{2}$ activated LPs and non-activated raw camel milk at room temperature.

effect due to the presence of higher levels of other indigenous antimicrobial components including the $\mathrm{H}_{2} \mathrm{O}_{2}$. It was reported that activation of LPs in camel milk decreased the multiplication of total bacteria for more than 12 hours of storage [40]. Other reports indicated that the activated LPs in milk had bacteriostatic effect against a mixed raw milk flora dominated by mesophilic bacteria [14].

On the other hand, $W$. confusa 22282 activated LPs retarded level of CC by $1.09 \log$ units as compared to the non-activated at 18 hours of storage showing 
that the activated LPs exhibited antimicrobial effect on the coliform microorganisms in raw camel milk. This finding is in agreement with the result of other experiments [24] who reported reduction of CC by $1.14 \mathrm{log}$ units in Saanen goats' milk activated with LPs compared to the non-activated milk. No significant difference $(\mathrm{P}>0.05)$ was observed in CC between the W. confusa 22282 and exogenous $\mathrm{H}_{2} \mathrm{O}_{2}$ activated LPs samples throughout the storage period which indicated that the treatments have comparable effect on the growth of coliforms in camel milk.

\subsection{Effect of Lactoperoxidase System Activation on Growth of Escherichia coli}

The activation of LPs by $W$. confusa 22282 and exogenous $\mathrm{H}_{2} \mathrm{O}_{2}$ in pasteurized camel milk remarkably reduced the growth rate of $E$. coli population compared their respective population in boiled milk throughout the storage period (Figure 3). This result indicated that the role of LP enzyme in boiled milk might be impaired in catalyzing the oxidation of thiocyanate by $\mathrm{H}_{2} \mathrm{O}_{2}$. The LPs improves keeping quality of milk pasteurized at $72^{\circ} \mathrm{C} / 15 \mathrm{~s}$ compared to milk heated to $80^{\circ} \mathrm{C} / 15$ seconds [41]. Similar findings [42] was reported that activation of LPs extended the keeping quality of pasteurized milk $\left(72^{\circ} \mathrm{C} / 15 \mathrm{~s}\right)$ inoculated with Pseudomonas aeruginosa, $S$. aureus and $S$. thermophilus while the milk heated at $80^{\circ} \mathrm{C} / 5 \mathrm{~s}$ and activated with the LPs had no effect on growth of these organisms. Moreover, this finding is supported by recommendation by FAO/WHO [8] that heating milk for 15 seconds at $80^{\circ} \mathrm{C}$, completely inactivates enzymatic activity of the milk might be because of the destruction of indigenous inhibitory components by the higher temperature. Indigenous enzymes are heat-labile and can easily be destroyed under the boiling conditions [43].

Similarly, the rate of $E$. coli growth in the LAB and exogenous $\mathrm{H}_{2} \mathrm{O}_{2}$ activated LPs in pasteurized camel milk was considerably lower than the rate in non-activated pasteurized milk (Figure 3). Reduction in microbial spoilage of LPs activated

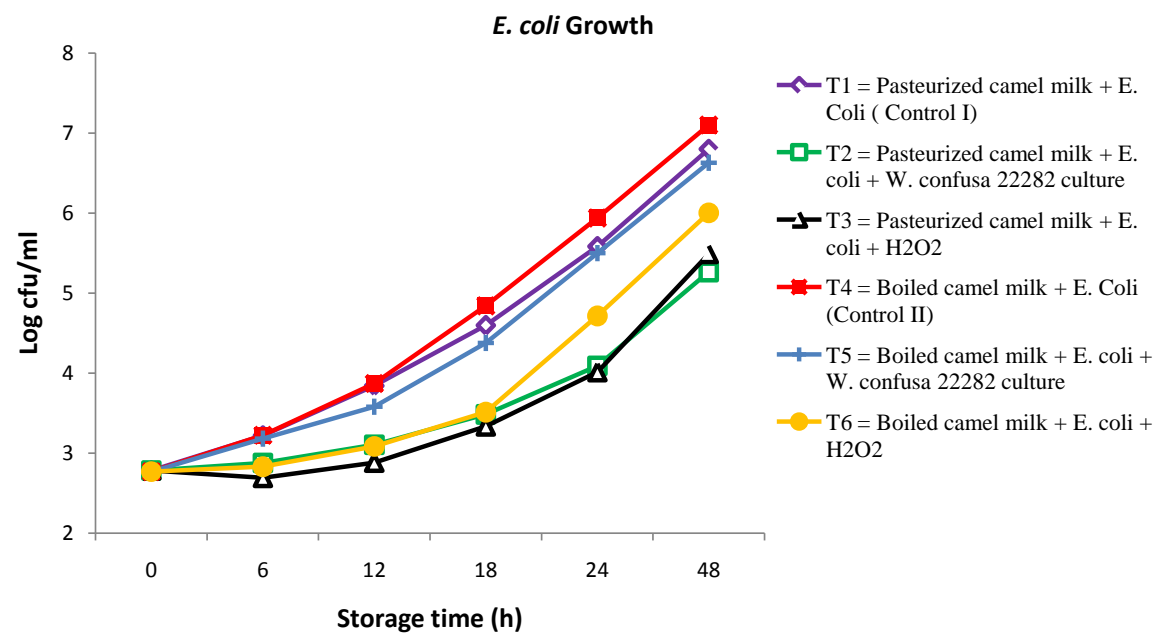

Figure 3. Grow and survival of $E$. coli in the LPs activated pasteurized and boiled camel milk for 48 hours. 
pasteurized cow milk inoculated with $E$. Coli compared to the non-activated one was also reported [44]. An inhibition of the growth of E. coli for 24 hours [45] and a nearly total inhibition of E. coli O157:H7 [21] was also reported in cow milk and in commercial fermented milk and traditional Madila activated with LPs, respectively.

No remarkable difference was observed in retarding $E$. coli population between the $W$. confusa 22282 activated and $\mathrm{H}_{2} \mathrm{O}_{2}$ activated LPs in the pasteurized camel milk except a better retarding effect in the LAB activated samples toward the end of the storage period, which might be due to continuous production of $\mathrm{H}_{2} \mathrm{O}_{2}$ in the milk (Figure 3). The $W$. confusa 22282 treated boiled milk had shown slight reduction compared to the untreated boiled milk samples might be because of the effects of residual LP in the milk [42] or due to production of metabolites by the LAB [46]. Metabolites produced by LAB were reported to affect the growth of E. coli, S. aureus, Salmonella spp. in food items [47]. On the other hand, the $\mathrm{H}_{2} \mathrm{O}_{2}$ treated boiled milk shown remarkable reduction in $E$. coli counts compared to the untreated boiled samples. This clearly indicated that $\mathrm{H}_{2} \mathrm{O}_{2}$ had antimicrobial effect by itself as supported by other finding [48].

\section{Conclusion}

The current study showed that LAB can produce $\mathrm{H}_{2} \mathrm{O}_{2}$ to activate the natural antimicrobial system in the milk. The optimization experiment indicated that $W$. confusa 22282 can produce sufficient amount of $\mathrm{H}_{2} \mathrm{O}_{2}$ in MRS broth. The activation of LPs by $W$. confusa 22282 as a source of $\mathrm{H}_{2} \mathrm{O}_{2}$ in raw camel milk significantly $(\mathrm{P}<0.05)$ reduced the rate of lactic acid development, TBC and CC compared to the non-activated samples at 12, 18, 24 and 48 hours of storage at room temperature. Similarly, the activation of LPs by $W$. confusa 22282 in pasteurized and boiled camel milk samples inoculated with $E$. coli as contaminant showed that the LPs activated pasteurized milk remarkably reduced the $E$. coli population compared to the $W$. confusa 22282 treated boiled milk throughout the storage period. The rate of growth of the E. coli population in the $W$. confusa 22282 activated LPs in pasteurized milk was also considerably lower than the rate in non-activated pasteurized milk. This indicated that pasteurization $\left(63^{\circ} \mathrm{C} / 30 \mathrm{mi}\right.$ nutes) cannot destroy the enzyme LP and the storage stability of the pasteurized milk samples was therefore due to the activation of the antimicrobial system in the milk. Generally, the present study showed that it is possible to activate the natural antimicrobial system in camel milk using $\mathrm{H}_{2} \mathrm{O}_{2}$-producing $\mathrm{LAB}(W$. confusa 22282) as a source of $\mathrm{H}_{2} \mathrm{O}_{2}$ in the presence of appropriate concentrations of natural thiocyanate in the milk. Therefore, it can be concluded that biological activation of LPs by $W$. Confusa 22282 in camel milk can substitute the chemical activation method provided that the milk has sufficient inherent thiocyanate.

\section{Acknowledgements}

The authors are grateful to Danish International Development Agency (DANIDA) 
for financing this research project. Haramaya University is highly appreciated for providing facilities to conduct the research.

\section{Conflicts of Interest}

The authors declare no conflicts of interest regarding the publication of this paper.

\section{References}

[1] Yohannes, M., Zeleke, M. and Getachew, G. (2007) Potentials of Camel Production in Babile and Kebribeyah Woredas of the Jijiga Zone, Somali Region, Ethiopia. Livestock Research for Rural Development, 19, 58.

[2] Mohammed, Y.K. (2003) Certain Aspects of the Dairy Systems in the Harar Milk Shed, Eastern Ethiopia. PhD Thesis Presented to the School of Graduate Studies of University of the Free State, Bloemfontein, 195 p.

[3] Farah, Z., Mollet, M., Younan, M. and Dahir, R. (2007) Camel Dairy in Somalia: Limiting Factors and Development Potential. Livestock Science, 110, 187-191. https://doi.org/10.1016/j.livsci.2006.12.010

[4] Eyassu, S. (2007) Handling, Preservation and Utilization of Camel Milk and Camel Milk Products in Shinile and Jijiga Zones, Eastern Ethiopia. Livestock Resources for Rural Development, 19, 6.

[5] Abdi, A.H., Seid, M.A. and Abdurehman, E.T. (2010) Town Camels: Pastoral Innovation in a Fast-Changing World. A Case Study from Gode Town, Somali Regional State, Ethiopia. International Conference on the Future Pastoralism at the Institute of Developmental Studies, University of Sussex and Feinstein International Center of Tufts University, 21-23 March 2011, 24.

[6] Tsehay, R. (2002) Small-Scale Milk Marketing and Processing in Ethiopia. Proceedings of a South-South Workshop, Anand, 13-16 March 2001, 352-367.

[7] Noor, I.M., Guliye, A.Y., Tariq, M. and Bebe, B.O. (2013) Assessment of Camel and Camel Milk Marketing Practices in an Emerging Peri-Urban Production System in Isiolo County, Kenya. Pastoralism: Research, Policy and Practice, 3, 28. https://doi.org/10.1186/2041-7136-3-28

[8] FAO and WHO (Joint Food and Agriculture and World Health Organizations) (2005) Benefits and Potential Application of Lactoperoxidase System of Raw Milk Preservation. Report of FAO/HWO Technical Meeting.

[9] Singh, V., Kaushal, S., Tyagi, A. and Sharma, P. (2011) Screening of Bacteria Responsible for the Spoilage of Milk. Journal of Chemical and Pharmaceutical Research, 3, 348-350.

[10] O'Connor, C.B. (1995) Rural Dairy Technology ILRI Training Manual I. International Livestock Research Institute (ILRI), Addis Ababa.

[11] Davidson, P.M. and Taylor, M.T. (2007) Chemical Preservatives and Natural Antimicrobial Compounds. In: Doyle, P., Beuchat, L.R. and Montville, T.J., Eds., Food Microbiology: Fundamentals and Frontiers, American Society for Microbiology Press, Washington DC, 713-734. https://doi.org/10.1128/9781555815912.ch33

[12] FAO (Food and Agricultural Organization of the United Nations) (2016) Technical and Investment Guidelines for Milk Cooling Centres: by Moffat, F., Khanal, S., Bennett, A., Thapa, T.B. and Malakaran George, S. Rome.

[13] IDF (International Dairy Federation) (1988) Code of Practice for Preservation of 
Raw Milk by Lactoperoxidase System. IDF, Belgium, Bulletin No. 234.

[14] FAO and WHO (Food and Agriculture Organization and World Health Organization) (2000) Joint FAO-WHO Expert Committee on Food Standards Program 2. 121-125.

[15] Eyassu, S., Buys, E.M. and Donki, E.F. (2005) Significance of the Lactoperoxidase System in the Dairy Industry and Its Potential Applications: A Review. Food Science and Technology, 16, 137-154. https://doi.org/10.1016/j.tifs.2004.11.002

[16] Gálvez, A., Abriouel, H., López, R.L. and Omar, N.B. (2007) Bacteriocin-Based Strategies for Food Biopreservation. International Journal of Food Microbiology, 120, 51-70. https://doi.org/10.1016/j.ijfoodmicro.2007.06.001

[17] Ross, R.P., Morgan, S. and Hill, C. (2002) Preservation and Fermentation: Past, Present and Future. International Journal of Food Microbiology, 79, 3-16. https://doi.org/10.1016/S0168-1605(02)00174-5

[18] Yap, P.S. and Gilliland, S.E. (2000) Comparison of Newly Isolated Strains of Lactobacillus delbrueckii subsp. lactis for Hydrogen Peroxide Production at $5^{\circ} \mathrm{C}$. Journal of Dairy Science, 83, 628-632. https://doi.org/10.3168/jds.S0022-0302(00)74922-8

[19] Fugl, A., Tesfemariam, B., Kiran, A., Hussain, S., Frederik, M.L., Iain, M.B., Yonas, H., Sørensen, K.I., Mitiku, E., Ipsen, R. and Hansen, E.B. (2017) Characterisation of Lactic Acid Bacteria in Spontaneously Fermented Camel Milk and Selection of Strains for Fermentation of Camel Milk. International Dairy Journal, 73, 19-24. https://doi.org/10.1016/j.idairyj.2017.04.007

[20] AOAC (Association of Official Analytical Chemists) (1990) Official Methods of Analysis. 15th Edition, Washington DC.

[21] Buys, E., Parry-Hanson, A. and Jooste, P. (2009) Inhibition of Escherichia coli O157:H7 in Commercial and Traditional Fermented Goat Milk by Activated Lactoperoxidase. Dairy Science and Technology, 89, 613-625.

https://doi.org/10.1051/dst/2009042

[22] IDF (International Dairy Federation) (2004) Milk and Milk Products Enumeration of Colony Forming Unit of Yeast and Mold. IDF Standard 94:2004, 2nd Edition, IDF, Brussels.

[23] AOAC (Association of Official Analytical Chemists) (2000) Official Methods of Analysis. 17th Edition, Washington DC.

[24] Eyassu, S., Buys, E.M., Donkin, E.F. and Petzer, I.M. (2004) Antibacterial Activity of the Lactoperoxidase System against Food-Borne Pathogens in Saanen and South African Indigenous Goat Milk. Food Control, 15, 447-452. https://doi.org/10.1016/S0956-7135(03)00120-8

[25] Murphy, S.C. (1996) Sources and Causes of High Bacteria Count in Raw Milk. Cornell University, Ithaca, 1-34.

[26] Njage, K.M.P. and Wangoh, J. (2008) Impact of the Lactoperoxidase System on Activity of Selected Lactic Starter Cultures in Camel Milk. Food, 2, 70-74.

[27] Kamau, P.M.N., Lamuka, P.O. and Wangoh, J. (2010) Effect of Lactoperoxidase-Thiocyanate-Hydrogen Peroxide System and Storage Temperature on Keeping Quality of Raw Camel Milk. African Journal of Food Agriculture Nutrition and Development, 10, 4185-4201. https://doi.org/10.4314/ajfand.v10i10.62897

[28] Bekele, A., Mitiku, E., Yonas, H. and Egon, B.H. (2017) Activation of Lactoperoxidase System: Evaluation of the Acidification Rate, Microbial Quality, and Shelf Life of Camel and Cow Milk. East African Journal of Sciences, 11, 107-116.

[29] Helen, N. and Eyassu, S. (2007) Effect of the Lactoperoxidase System and Container 
Smoking on the Microbial Quality of Cows' Milk Produced in Kombolcha Woreda, Eastern Ethiopia. Livestock Research for Rural Development, 19, 157.

[30] Korhonen, H. (1980) A New Method for Preserving Raw Milk-The Lactoperoxidase Antibacterial System. World Animal Review, 35, 23-29.

[31] Yong, L., Wang, Y., Yang, D., Liu, Z., Abernethy, G. and Li, J. (2017) Investigation of Concentration of Thiocyanate Ion in Raw Cow's Milk from China, New Zealand and the Netherlands. Food Chemistry, 215, 61-66. https://doi.org/10.1016/j.foodchem.2016.07.130

[32] Secor, J.B., Conn, E.E., Dunn, J.E. and Seigler, D.S. (1976) Detection and Identification of Cyanogenic Glycosides in Six Species of Acacia. Phytochemistry, 15, 1703-1706. https://doi.org/10.1016/S0031-9422(00)97460-0

[33] CAC (Codex Alimentarius Commission) (1991) Guidelines for the Preservation of Raw Milk by Use of the Lactoperoxidase System. CAC-GL 13-1991.

[34] Saito, M., Seki, M., Lida, K. and Nakayama, H. (2007) A Novel Agar Medium to Detect Hydrogen Peroxide-Producing Bacteria Based on the Prussian Blue-Forming Reaction. Microbiology and Immunology, 51, 889-892. https://doi.org/10.1111/j.1348-0421.2007.tb03971.x

[35] Enitan, A., Adeyemo, J. and Ogunbanwo, S.T. (2011) Influence of Growth Conditions and Nutritional Requirements on the Production of Hydrogen Peroxide by Lactic Acid Bacteria. African Journal of Microbiology Research, 5, 2059-2066. https://doi.org/10.5897/AJMR11.128

[36] Adesokan, I.A., Ekanola, Y.A. and Okanlawon, B.M. (2010) Influence of Cultural Conditions on Hydrogen Peroxide Production by Lactic Acid Bacteria Isolated from Some Nigerian Traditional Fermented Foods. African Journal of Microbiology Research, 4, 1991-1996.

[37] Ito, A., Sato, Y., Kudo, S., Sato, S., Nakajima, H. and Toba, T. (2003) The Screening of Hydrogen Peroxide-Producing Lactic Acid Bacteria and Their Application to Inactivating Psychrotrophic Food-Borne Pathogens. Current Microbiology, 47, 231-236. https://doi.org/10.1007/s00284-002-3993-1

[38] Asaah, N.O., Fonteh, F., Kamga, P., Mendi, S. and Imele, H. (2007) Activation of the Lactoperoxidase System as a Method of Preserving Raw Milk in Areas without Cooling Facilities. African Journal of Food Agriculture Nutrition and Development, 7, 1-15.

[39] Ramet, J.P. (2001) The Technology of Making Cheese from Camel Milk (Camelus dromedarius). Animal Production and Health Paper 113. FAO, Rome.

[40] Kamau, M.P.N. and Wangoh, J. (2010) Use of the Lactoperoxidase System to Enhance Keeping Quality of Pasteurized Camel Milk. Food, 4, 61-63.

[41] Lewis, M. and Heppel, N. (2000) Continuous Thermal Processing of Foods, Pasteurization and UHT Sterilization. Aspen Publishers, Inc., Gaithersburg.

[42] Marks, N.E., Grandison, A.S. and Lewis, M.J. (2001) Challenge Testing of the Lactoperoxidase System in Pasteurized Milk. Journal of Applied Microbiology, 91, 735-741. https://doi.org/10.1046/j.1365-2672.2001.01435.x

[43] Fox, P.F. and Kelly, A.L. (2006) Indigenous Enzymes in Milk: Overview and Historical Aspects-Part 1. Review. International Dairy Journal, 16, 500-516. https://doi.org/10.1016/j.idairyj.2005.09.013

[44] Dajanta, K., Chukeatirote, E. and Apichartsrangkoon, A. (2008) Effect of Lactoperoxidase System on Keeping Quality of Raw Cow's Milk in Thailand. International Journal of Dairy Science, 3, 112-116. https://doi.org/10.3923/ijds.2008.112.116 
[45] Garcia-Graells, C., Valckx, C. and. Michiels, C.W. (2000) Inactivation of Escherichia coli and Listeria innocua in Milk by Combined Treatment with High Hydrostatic Pressure and the Lactoperoxidase System. Applied Environmental Microbiology, 66, 4173-4179. https://doi.org/10.1128/AEM.66.10.4173-4179.2000

[46] Ammor, S., Tauveron, G., Dufour, E. and Chevallier, I. (2006) Antibacterial Activity of Lactic Acid Bacteria against Spoilage and Pathogenic Bacteria Isolated from the Same Meat Small-Scale Facility 1-Screening and Characterization of the Antibacterial Compounds. Food Control, 17, 454-461.

https://doi.org/10.1016/j.foodcont.2005.02.006

[47] Ham, J.S., Kim, H.S., Hong, K.H., Kim, J.G., Geong, S.G., Chae, H.S., Ahn, J.N., Kang, D.K. and Kim, H.U. (2003) Inhibitory Activity of Lactic Acid Bacteria against Hazardous Microbes. Asian-Australasian Journal of Animal Science, 16, 1550-1554. https://doi.org/10.5713/ajas.2003.1550

[48] Thomas, E.L., Milligan, T.W., Joyner, R.E. and Jefferson, M.M. (1994) Antibacterial Activity of Hydrogen Peroxide and the Lactoperoxidase-Hydrogen Peroxide-Thiocyanate System against Oral Streptococci. Infection and Immunity, 62, 529-535.

https://doi.org/10.1128/IAI.62.2.529-535.1994 